\title{
Small Intestine Cancer pN1 TNM Finding v8
}

National Cancer Institute

\section{Source}

National Cancer Institute. Small Intestine Cancer pN1 TNM Finding v8. NCI Thesaurus. Code C133875.

Small intestine cancer with metastasis in one or two regional lymph nodes. (from AJCC 8th Ed.) 